\title{
A 10-YEAR EVALUATION OF THE PERFORMANCE OF FOUR ELM CULTIVARS IN CALIFORNIA, U.S.
}

\author{
by L.R. Costello', S.R. Scott', and C.M. Drake ${ }^{3}$
}

\begin{abstract}
In 1992, three elm (Ulmus spp.) cultivars reported to have tolerance to Dutch elm disease (DED) were planted in a field plot in Atherton, California, U.S. Cultivars included 'Prospector', 'Frontier', and 'American Liberty'. A fourth cultivar, 'Valley Forge', was added to the plot in 1999. American elms grown from seed were planted as controls. In the 10-year period from 1992 to 2002, tree height and trunk diameter were measured annually, and inspections for DED infections, elm leaf beetle activity, and other pests were conducted. In August 2003, one 'American Liberty' was found to be infected with DED. This is the only tree that has shown infection symptoms since the beginning of the study. Elm leaf beetle activity was highest in 1993 and 1994, causing substantial injury to 'American Liberty', 'Frontier', and controls. 'Prospector' sustained little injury. Other pest activity has been slight in most years. In 2002, 'Frontier', 'American Liberty', and controls were found to have equivalent trunk diameter growth, and all were significantly larger than 'Prospector'. After 10 years, 'Frontier' was tallest [11.3 m (37 ft)], 'Prospector' was shortest [6.9 m (23ft)], and 'American Liberty' and controls were in between [9.6 and 10.3 m (32 and $34 \mathrm{ft}$ ), respectively]. 'Valley Forge' was monitored for 3 years and then removed from the study because of poor structure.

Key Words. Dutch elm disease; elm cultivars; disease resistance; elm leaf beetle; pest tolerance.
\end{abstract}

Over the past 50 years, Dutch elm disease (DED) has caused a serious decline in the elm population in California, U.S. Although total mortality is not known, records indicate that 2,849 trees infected with DED were removed from 1975 to 1990, with virtually all the cases coming from the San Francisco Bay Area and Central Valley (California Department of Forestry and Fire Protection 1990). Although DED was first detected in California in 1975, isolations from annual rings indicate that it may have been present since 1953 (Tidwell 1982). Consequently, cases occurring before 1975 are not recorded, but the number may approach that from 1975 to 1990. Many more elms have died since 1990, but complete records have not been maintained. Collectively, from 1953 to the present, thousands of elms have been removed because of DED. With new infections continuing to occur and few elms being replanted, populations continue to decline.

In the past 10 years, however, there has been considerable interest in re-establishing the California elm population (Greenfield 1996). Many cities are interested in planting elms for their distinctive form and notable resilience in urban environments. Recognizing that host resistance is the most effective method of pest control, it was proposed that DEDresistant elms could be used to restore elm populations. Over the past 20 years, extensive research efforts in the eastern United States have led to the introduction of many new cultivars with acceptable levels of DED tolerance (Becker 1996; Dunn 2000; Townsend 2000), with considerable attention being focused on American elm (Ulmus americana L.) (Smalley et al. 1993; Townsend and Douglass 2001). Although many of the introduced cultivars likely are suitable for California, controlled field studies evaluating their performance have not been conducted in a Mediterranean climate zone. Rather, all field tests have been limited to states with temperate climate zones, principally Maryland, Ohio, Illinois, and Wisconsin (Ware 1992; Townsend 2000; Kuser and Polanin 2001). Because pest-host interactions and species growth characteristics vary with climate, this study was initiated to evaluate select cultivars in California, where winters are wet and cool, and summers are warm and dry. Specifically, our objectives were to (1) evaluate four elm cultivars for DED tolerance, tolerance to other pests, growth habits, and structural characteristics when grown in a Mediterranean climate, and (2) identify DED-tolerant cultivars suitable for planting in California.

\section{MATERIALS AND METHODS}

Four cultivars were selected for evaluation: 'Prospector' ( $U$. wilsoniana Schneid.), 'Frontier' (U. carpinifolia Gleditsch $\times U$. parvifolia Jacq.), 'American Liberty' (U. americana L.), and 'Valley Forge' (U. americana L.).

'Prospector' elm is an introduction of the U.S. National Arboretum (Townsend et al. 1991b). In laboratory and field trials at the USDA Research Center in Delaware, Ohio, 'Prospector' showed high tolerance to DED (Townsend et al. 1991b; Townsend and Douglass 2001) and elm leaf beetle (ELB) (Xanthogaleruca luteola) (Hall and Townsend 1987). 'Prospector' is a deciduous tree with a dense, vase-shaped canopy similar to American elm. It has a moderately fast growth rate to $15.2 \mathrm{~m}(50 \mathrm{ft}$ ) tall and a crown spread of 7.6 $\mathrm{m}(25 \mathrm{ft})$ at maturity. Leaves are obovate and are orange-red in spring and yellow in fall.

'Frontier' elm is another introduction of the U.S. National Arboretum (Townsend et al. 1991a). It was selected from a controlled pollination of spring-flowering U. carpinifolia and 
fall-flowering U. parvifolia. 'Frontier' has high tolerance to DED (Townsend et al. 1991a; Townsend and Douglass 2001), moderate resistance to the elm leaf beetle (Hall et al. 1987), and appears to be resistant to natural infections of elm yellows (Townsend et al. 1991a). Warren (2000) indicates that it is a medium-sized tree growing to $12.2 \mathrm{~m}$ (40 ft) tall, with a crown spread of $9.1 \mathrm{~m}$ (30 ft). 'Frontier' is upright-pyramidal in shape (more upright than U. parvifolia) and has smooth, gray-green bark. Foliage is similar in size and shape to that of U. parvifolia and is a striking red-purple in fall.

'American Liberty' elm is the product of a breeding program led by E. Smalley at the University of Wisconsin (Smalley et al. 1993). The six parent trees from which 'American Liberty' has been propagated are the survivors of more than 60,000 American elm seedlings being inoculated with a mixture of North American strains of DED. Although initially reported to be resistant to DED, 'American Liberty' did not perform well in subsequent inoculation tests by Townsend and Douglass (2001) and Townsend et al. (1995). In California, American elm has been reported to be more tolerant to ELB than English elm (U. procera) and Siberian elm (U. pumila) but less tolerant than Chinese elm ( $U$. parvifolia) (Luck and Scriven 1979). Growth habits, leaf size and color, and structure of 'American Liberty' are typical of the species. The Elm Research Institute (Keene, New Hampshire) has propagated and distributed this cultivar since 1983

'Valley Forge' was introduced by the U.S. National Arboretum in 1995 (Townsend 2000). Of all American elm seedlings screened, 'Valley Forge' was found to have the highest DED tolerance (Townsend and Douglass 2001). This selection has a classic vase-shaped American elm form with a full, dense canopy. Leaf size and shape are typical of American elm, and fall color is yellow.

In 1989 and 1990, 'Prospector', 'Frontier', and 'American Liberty' elms were shipped to the University of California's Bay Area Research and Extension Center (BAREC) in Santa Clara. Rooted cuttings of 'Prospector' and bare-root stock of 'Frontier' were supplied by the U.S. National Arboretum (Delaware, Ohio), while rooted cuttings of 'American Liberty' were supplied by the Elm Research Institute (Keene, New Hampshire). Rooted cuttings of 'Valley Forge' were received from the U.S. National Arboretum in 1997. DEDsensitive American elm seedlings were used as controls. Seed was provided by the U.S. National Arboretum (from nonresistant elm sources in Delaware, Ohio) and was germinated at BAREC in 1990.

All trees were initially planted in $3.8 \mathrm{~L}$ ( 1 gal) or $19 \mathrm{~L}$ (5 gal) containers and then transplanted into $57 \mathrm{~L}$ (15 gal) containers the following year. Trees were irrigated as needed, fertilized with Osmocote ${ }^{\circledR}$ (14-14-14), and pruned to maintain a central leader.

\section{Field Plot}

In 1992, trees were planted in a field plot (Figure 1) located at Holbrook-Palmer Park in Atherton, California, about 40 $\mathrm{km}(25 \mathrm{mi})$ south of San Francisco. Formerly a private estate known as Elmwood, the park contained approximately 125 mature elms prior to 1978, when the first DED infection was confirmed. From 1978 to 1991, 52 trees were removed because of DED. Laboratory confirmations of the aggressive strain and B mating type of the DED fungus (Ophiostoma novo-ulmi) were made by the California Department of Food and Agriculture and the California Department of Forestry and Fire Protection. Only the aggressive strain and the B mating type have been reported in California (Markham and Haley 1990).

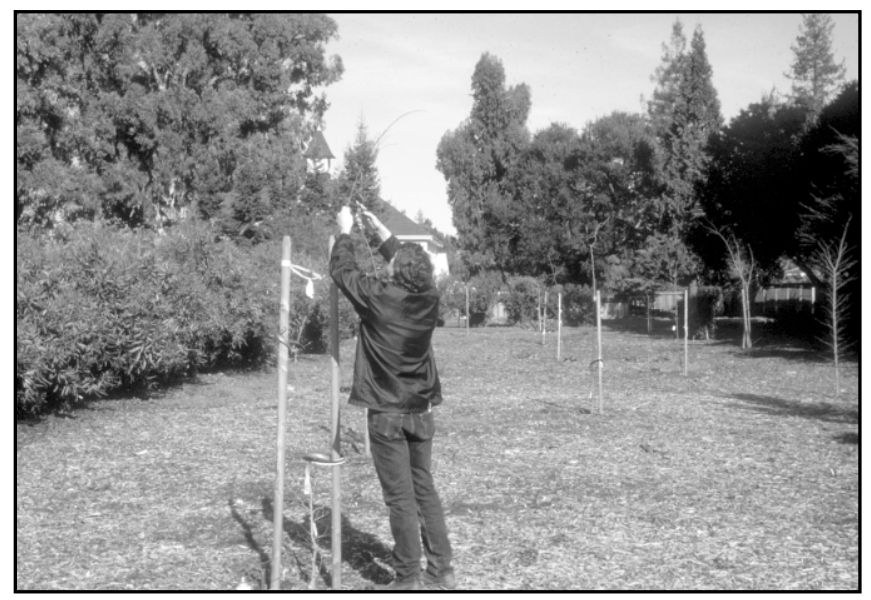

Figure 1. In 1992, 15 trees of each cultivar ('Prospector', 'Frontier', 'American Liberty') and controls (American elm seedlings) were planted in a field plot in Atherton, California. 'Valley Forge' was added to the plot in 1999.

The town of Atherton is approximately $16 \mathrm{~m}(53 \mathrm{ft})$ above sea level and has a Mediterranean climate. Temperatures range from an average low of $3.9^{\circ} \mathrm{C}\left(39^{\circ} \mathrm{F}\right)$ in January to an average high of $27^{\circ} \mathrm{C}\left(81^{\circ} \mathrm{F}\right)$ in July, with night and early morning fog common in the summer. Average precipitation is $51 \mathrm{~cm}$ (20.2 in.), occurring principally from November through April.

Trees were planted in 15 randomized complete blocks, with one tree of each cultivar and a control (DED-sensitive American elm seedling) in each block (15 replicates). Although trees were planted at least $5 \mathrm{~m}(16.5 \mathrm{ft})$ apart, spacing varied due to the irregular plot shape (Figure 1).

At planting, roots were separated from the root ball to disrupt circling and/or girdling roots. After planting, all trees were staked but not fertilized. Trees were hand-watered for 1 month then irrigated during the summer months with an automatic irrigation system. Wood-chip mulch was spread 
across the plot to control weeds and reduce water evaporation from the soil. In addition to mulch, weeds were controlled by discing and contact herbicide application.

Following methods described by Costello (2002), trees were pruned annually during the dormant season to maintain a central leader and establish scaffold limbs. Pruning to reduce end weights and maintain clearance was completed as needed. After each tree was pruned, pruning tools were sterilized with Lysol ${ }^{\circledR}$ disinfectant spray (Reckitt Benckiser, Inc.).

\section{Tree Measurements and Evaluations}

From 1992 to 2002, trunk diameter and tree height were measured annually during the dormant season. For the first 4 years, diameter was measured at $0.3 \mathrm{~m}(1 \mathrm{ft})$ above ground level and then at $1.37 \mathrm{~m}(4.5 \mathrm{ft})$ for the remainder of the study. Diameter measurements were made with a Plastical ${ }^{\circledR}$ digital caliper and height measurements with a Tel-O-Pole $®$ measuring stick (Hastings Fiber Glass Products, Hastings, MI). Pruning requirements (amount and frequency) and structural characteristics (angle of branch attachments, branch diameter relative to trunk diameter, and central leader dominance) were evaluated subjectively during the growing and dormant seasons. In addition to observations of fall color and tendency to develop root suckers, the time of flowering, seeding, and leafing out were noted for each cultivar. Aside from inspecting for girdling roots, evaluations of root characteristics were not made.

\section{Pest Monitoring}

Trees were not inoculated with either of the DED pathogens Ophiostoma ulmi or O. novo-ulmi. Rather, they were planted in an area with a confirmed history of DED and, therefore, exposed to ambient disease pressure. During the growing season, all trees were monitored for DED symptoms (wilt, branch dieback, discoloration of xylem). In 1994, funnel traps (developed by the California Dutch Elm Disease Project) were baited with pheromone (Multilure $\AA$ ) and used in the field plot to confirm the presence of the smaller European elm bark beetle (Scolytus multistriatus), the DED vector.

Trees were monitored for signs and symptoms of elm leaf beetle (Xanthogaleruca luteola), European elm scale (Gossyparia spuria), woolly elm aphid (Eriosoma americana), and anthracnose (Stegophora ulmea). Based on a visual inspection of leaves, elm leaf beetle (ELB) injury was scored from 0 (no injury) to 10 (100\% defoliation), and feeding was characterized as larval or adult (Hall 1986). European elm scale, aphid, and anthracnose presence/injury were assessed and rated as being slight, moderate, or heavy.

\section{Statistical Methods}

Trunk diameter, tree height, and ELB injury were analyzed using a randomized, complete blocks design. Each outcome was analyzed separately for each year for which data were available. Multiple comparisons to identify which elm cultivars were different were carried out using the Bonferroni method. Residual plots were obtained to assess model adequacy. Statistical calculations were performed in SAS version 8.2.

\section{RESULTS \\ Trunk Diameter}

Trunk diameter of 'Frontier' was significantly greater than controls and other cultivars in $1992(\mathrm{P}=0.0001)$. 'American Liberty' and controls were not significantly different in 1994 and 1996 but were significantly larger than 'Prospector' $(\mathrm{P}=$ 0.0001). In 2000 and 2002, trunk diameters of 'Frontier', 'American Liberty', and controls were not significantly different, with values ranging from 20.9 to $21.1 \mathrm{~cm}$ (8.36 to 8.44 in.), while trunk diameter of 'Prospector' was significantly smaller $(\mathrm{P}=0.0001)$ than controls and other cultivars (Figure 2).

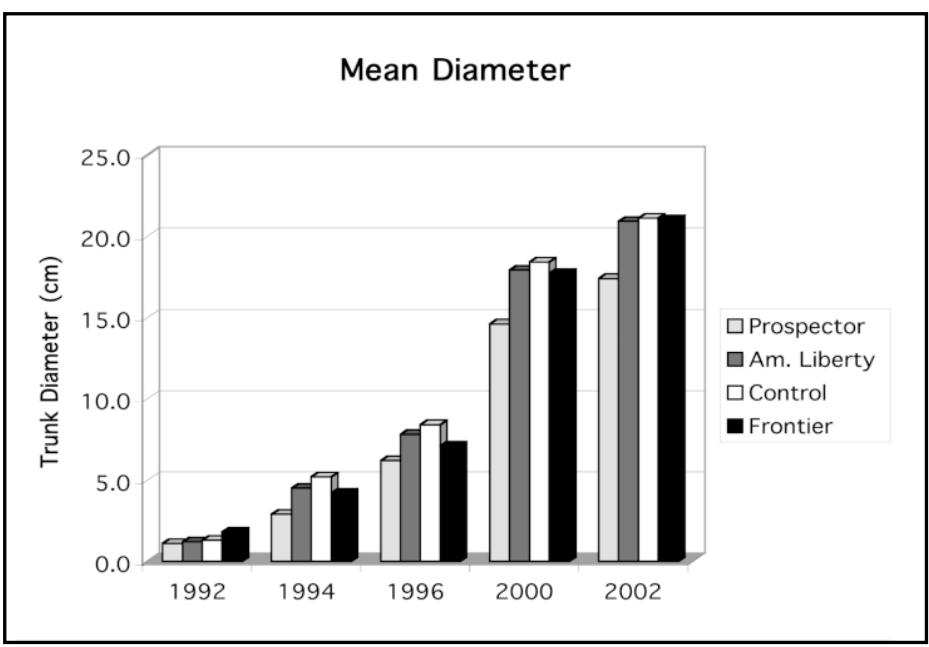

Figure 2. Trunk diameter growth $(\mathrm{cm})$ for selected years from 1992 to 2002 for cultivars and controls (American elm

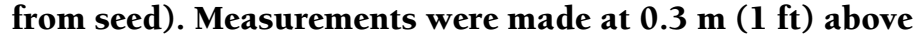
ground level from 1992 to 1994 and at $1.37 \mathrm{~m}(4.5 \mathrm{ft})$ from 1996 to 2002. After 10 years (2002), 'Frontier', 'American Liberty', and controls were not significantly different from one another, but all were significantly larger than 'Prospector' $(P=0.0001)$.

\section{Tree Height \\ After 2 years (1994), 'Frontier', 'American Liberty', and controls were virtually equivalent in height, while 'Prospec- tor was significantly shorter $(\mathrm{P}=0.0001)$ than controls and other cultivars (Figure 3). Although differences in height for 'Frontier', 'American Liberty', and controls were not signifi- cant from 1996 to 2000, 'Frontier' was significantly taller $(\mathrm{P}=0.0001)$ than other cultivars in 2002. Controls $[10.3 \mathrm{~m}$ $(34 \mathrm{ft})]$ and 'American Liberty' [9.6 m (32 ft)] were not significantly different after 10 years, but both were signifi- cantly taller than 'Prospector' $(\mathrm{P}=0.0001)$.}




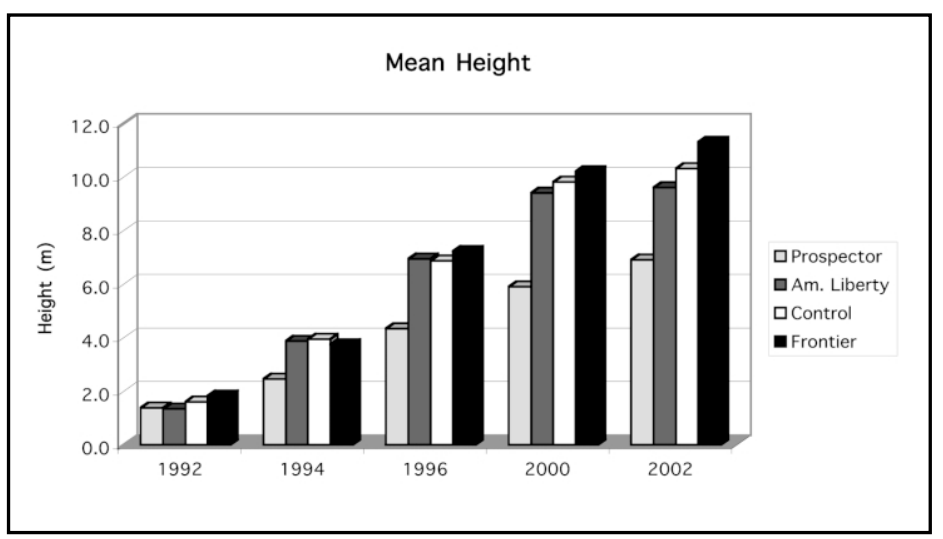

Figure 3. Tree height (m) from 1992 to 2002 for cultivars and controls (American elm grown from seed). 'Prospector' was significantly shorter than other cultivars and controls in all years except 1992. From 1994 to 2000, 'Frontier', 'American Liberty', and controls were not significantly different. After 10 years, 'Frontier' was significantly taller than 'American Liberty' and controls, which were significantly taller than 'Prospector' $(P=\mathbf{0 . 0 0 0 1})$.

Growth measurements for 'Valley Forge' are not included in Figures 2 and 3 because it was added to the plot in 1999. From 2000 to 2002, trunk diameter more than tripled, from 2.2 to $7.5 \mathrm{~cm}$ (0.88 to $3 \mathrm{in}$.), while height increased from 2.7 to $4.1 \mathrm{~m}(8.9$ to $13.5 \mathrm{ft})$.

\section{Pest Activity}

In August 2003, DED symptoms (wilting and yellowing of leaves; discoloration and streaking of wood) were noted in one 'American Liberty' elm. Branch samples submitted to the Plant Pest Diagnostics Center of the California Department of Food and Agriculture (Sacramento, California) were confirmed to be infected with Ophiostoma novo-ulmi. Only a single 'American Liberty' tree was affected: 'Frontier', 'Prospector', and controls have not shown similar symptoms. Prior to this determination, no trees had been found to be infected with DED.

Aside from 1993 and 1994, ELB injury was relatively low in most years (Figure 4). For 6 out of 10 years, injury was less than 0.5 , or virtually no injury was found. In 1995 and 1996, levels rose slightly above 1.0 for 'American Liberty' and controls, but injury was assessed as being minor. In 1994, minor to moderate levels of injury were found, with 'American Liberty', 'Frontier', and controls showing similar levels, ranging from 2.4 to 3.1, which were not significantly different. 'Prospector' exhibited a significantly lower level of injury (1.0) than other cultivars and controls. Injury was most severe in 1993, with most damage resulting from adult feeding in September (Figure 5). Injury levels for 'American Liberty', 'Frontier', and controls were not significantly different, but 'Prospector' injury was significantly lower than other cultivars and controls.

Although European elm scale was observed on all cultivars, populations were small and injury was not apparent. Infestations on 'American Liberty' and control trees were larger, however, than those found on 'Frontier' and 'Prospector'. Aphids (Eriosoma americana) caused leaf curling on 'American Liberty' and controls, while anthracnose injury was not detected on any of the cultivars.

\section{Structural Characteristics and Pruning Requirements}

'Prospector' required intensive training as a young tree. During the first 2 years after planting, substantial formative pruning was needed to establish a central leader, and most trees needed staking to maintain an upright growth habit. After 2 years, however, 'Prospector' developed sufficient trunk diameter to support itself, and a central leader became established in most cases (Figure 6). Branch attachments were rated as being relatively strong (i.e., good size relationship between branch and trunk, and wide angle of attachment).

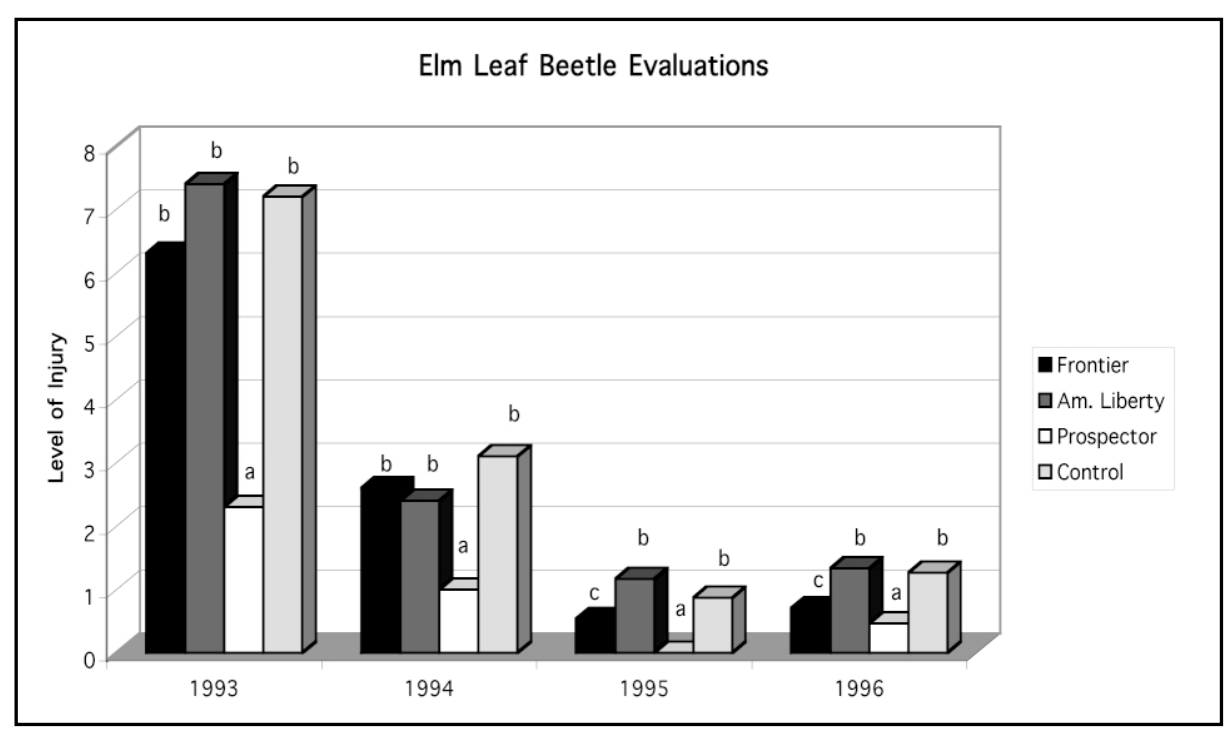

Figure 4. Visual ratings of elm leaf beetle injury: $0=$ no injury and $10=100 \%$ canopy defoliation. Results are given for years when ratings were greater than 1.0 for one or more cultivars. Injury ratings were less than 1.0 in 6 out of 10 years. Data bars with different letters denote significant differences among cultivars for the year of the evaluation $(P=0.001$ for 1993 and $1994 ; P=0.05$ for 1995 and 1996). 


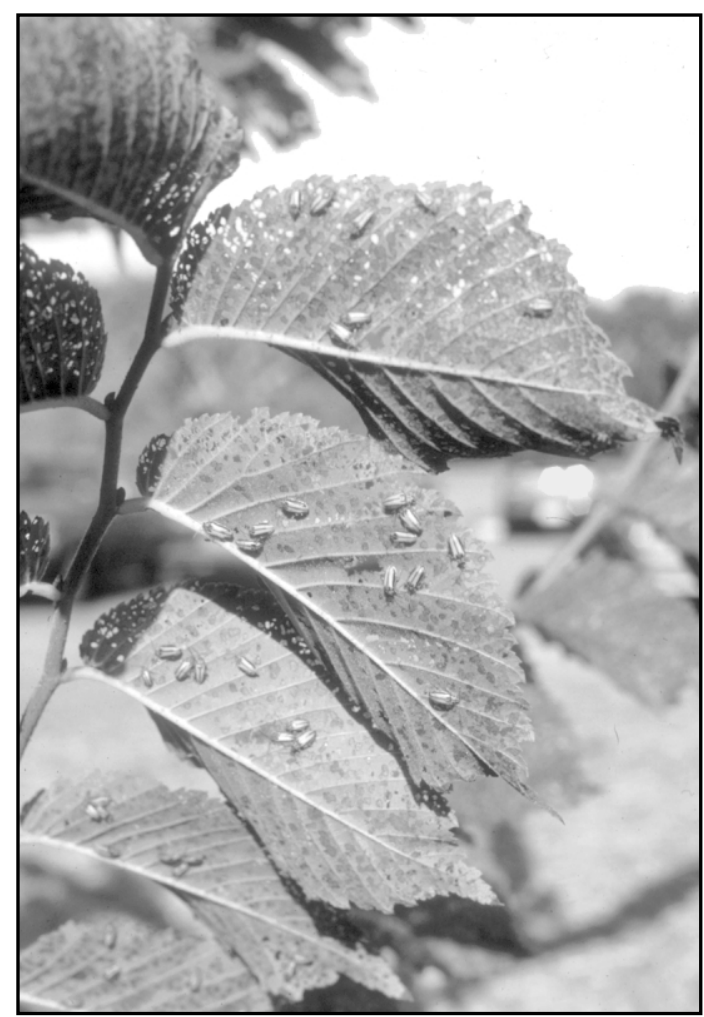

Figure 5. Foliar injury from elm leaf beetle was greatest in 1993 and 1994. During these years, 'Frontier', 'American Liberty', and controls sustained relatively high levels of injury, while injury to "Prospector' was minor. Adult feeding in late summer (as shown here) caused the highest levels of injury.

Pruning requirement was rated as being high when trees were young (years 1-3) but moderate to low as the trees matured.

Of all the cultivars, 'Frontier' required the least amount of pruning. Having a natural tendency to develop a dominant central leader, 'Frontier' developed an upright form with good size relationships between branches and the trunk, and strong attachments. Close spacing between branches required thinning cuts to establish scaffolds. Pruning requirement was rated as being low.

'American Liberty' developed an upright growth habit when young, but codominant stems needed to be removed on many trees. Scaffold branch angles tended to be acute, and included bark was noted in many attachments. During winter storms in 2001 and 2002, branches broke at the attachment on several trees. One tree needed to be removed because a lower scaffold failed, causing a split in the trunk. Pruning requirement was rated as moderate.

After 3 years, 'Valley Forge' exhibited very poor structure, and all but one of the trees were removed in spring 2002. This cultivar tended to be very fast growing and highly "branch dominant." Despite intensive pruning to suppress branch growth and establish a central leader, trees developed a strongly diffuse growth habit, with individual branches growing as much as $3.3 \mathrm{~m}(10 \mathrm{ft})$ in a year. Neither a reduction in growth nor an improvement in structure was found after structural pruning removed as much as $60 \%$ of the canopy in the dormant season.

\section{DISCUSSION}

Although all three cultivars were disease-free through 10 years, a confirmed infection in 'American Liberty' in 2003 indicates that it is susceptible to DED in California. Because only one tree has been infected, however, the susceptibility of 'American Liberty' relative to controls and other cultivars cannot be determined. Monitoring of trees for DED infection will continue over the next 10 years, and statistically significant differences may become apparent with time.

Differences in ELB susceptibility of cultivars have implications regarding maintenance requirements. ELB populations vary from year to year in California (Costello et al. 1990; Dreistadt and Dahlsten 1990), and management requirements for cultivars will vary with ELB population level. When populations are low, little management will be needed for any of the cultivars. When populations are high, 'American Liberty' and 'Frontier' will sustain injury, and pest management inputs may be needed to maintain acceptable appearance. However, 'Prospector' likely will require little or no management for ELB regardless of population size.

Although European elm scale and aphids were found, injury levels were assessed as slight, and management requirements are likely to be minimal.

Differences in growth and structural characteristics have implications regarding both the use of these cultivars in urban landscapes and the level of input needed to maintain good form and strong structure. These characteristics and others are addressed in the following summary assessments for each cultivar.

\section{'Prospector'}

Although it needed substantial training in the first 2 to 3 years, 'Prospector' developed an upright, round-headed form with strong branch attachments (Figure 6). Because of its round-headed form, 'Prospector' will likely not serve as a substitute for American elm, but it appears to have promise as a moderate-sized tree for streets, parks, or yards, and particularly in areas with sizable ELB populations. It may not be a good selection in areas with high boron concentrations (soil or water), however. Marginal necrosis symptomatic of boron toxicity was found on leaves of 'Prospector' for all years of the study. Tissue analysis found boron concentrations ranging from 158 to $274 \mathrm{ppm}$. Boron tissue levels greater than $200 \mathrm{ppm}$ are considered injurious for many landscape species (Costello et al. 2003). Interestingly, equivalent levels of boron were found in leaves of 'Frontier' and 'American Liberty', suggesting that 'Prospector' may have a greater sensitivity to boron than the other elm cultivars. 


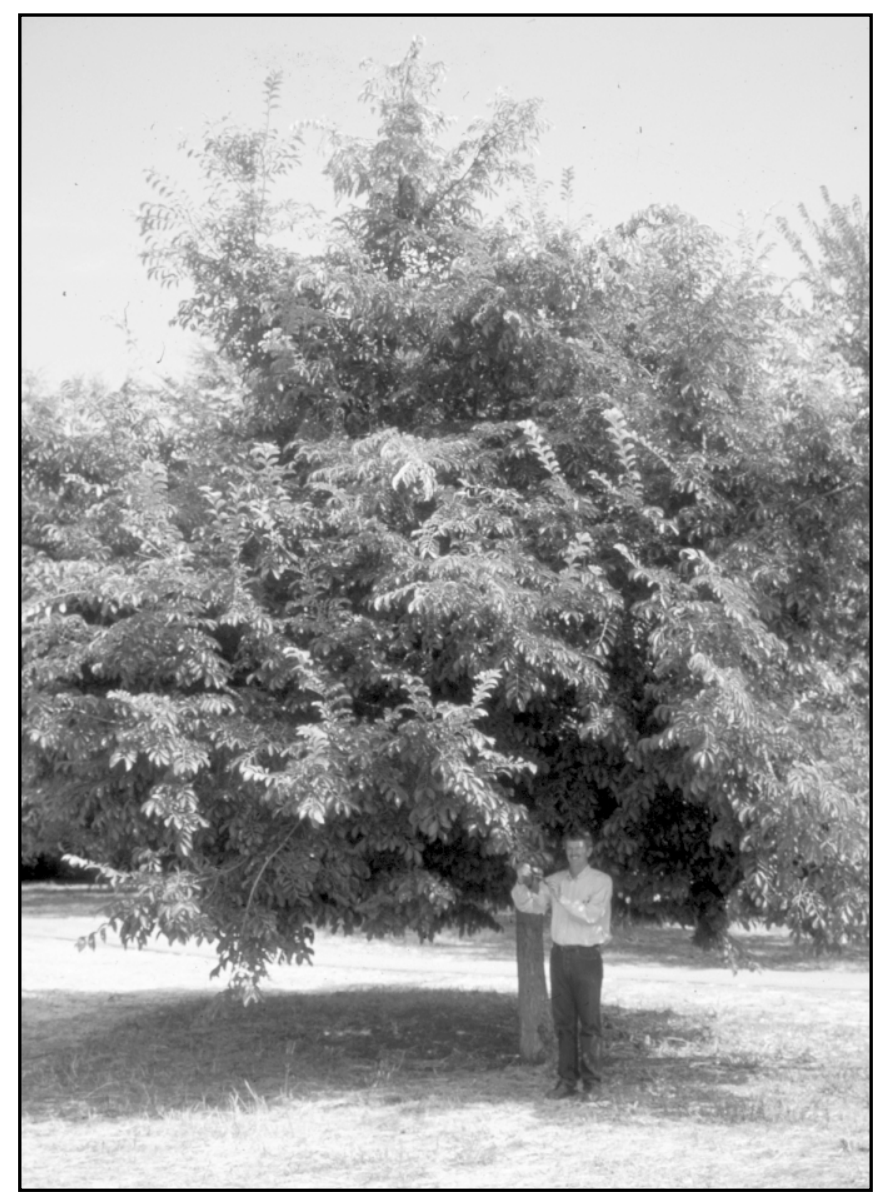

Figure 6. 'Prospector' developed a round-headed canopy with a weeping growth habit. Initially, trunk diameter growth was slow and trees needed staking. After 3 years, trunk growth increased and the trees were able to support themselves. Ten years after planting, this tree is approximately $6.5 \mathrm{~m}$ (21.5 ft) tall.

\section{'Frontier'}

Changing in form from pyramidal when young to oblong when maturing, 'Frontier' developed a dominant central leader, strong branch attachments, and good branch-to-trunk size relationships (Figure 7). Reaching a mean height of $11.5 \mathrm{~m} \mathrm{(35}$ ft) after 10 years indicates that 'Frontier' can achieve mature dimensions in a relatively short period of time. In fact, Warren's (2000) estimate of $13.1 \mathrm{~m}$ (40 ft) as the mature height for 'Frontier' may be an underestimate; two trees measured $12.1 \mathrm{~m}$ (37 ft) after 10 years. However, after 19 years from seed in Delaware, Ohio (temperate climate zone), Townsend et al. (1991a) reported that 'Frontier' reached $8.2 \mathrm{~m}$ (26 ft) tall. Strong structure, rapid growth rate, attractive leaf color in spring and fall, and relatively low pruning requirement suggest that 'Frontier' has promise in many urban locations in California, and most notably as a street tree. 'Frontier', however, has only moderate ELB tolerance, so injury will occur in locations and years where and when ELB populations are high.

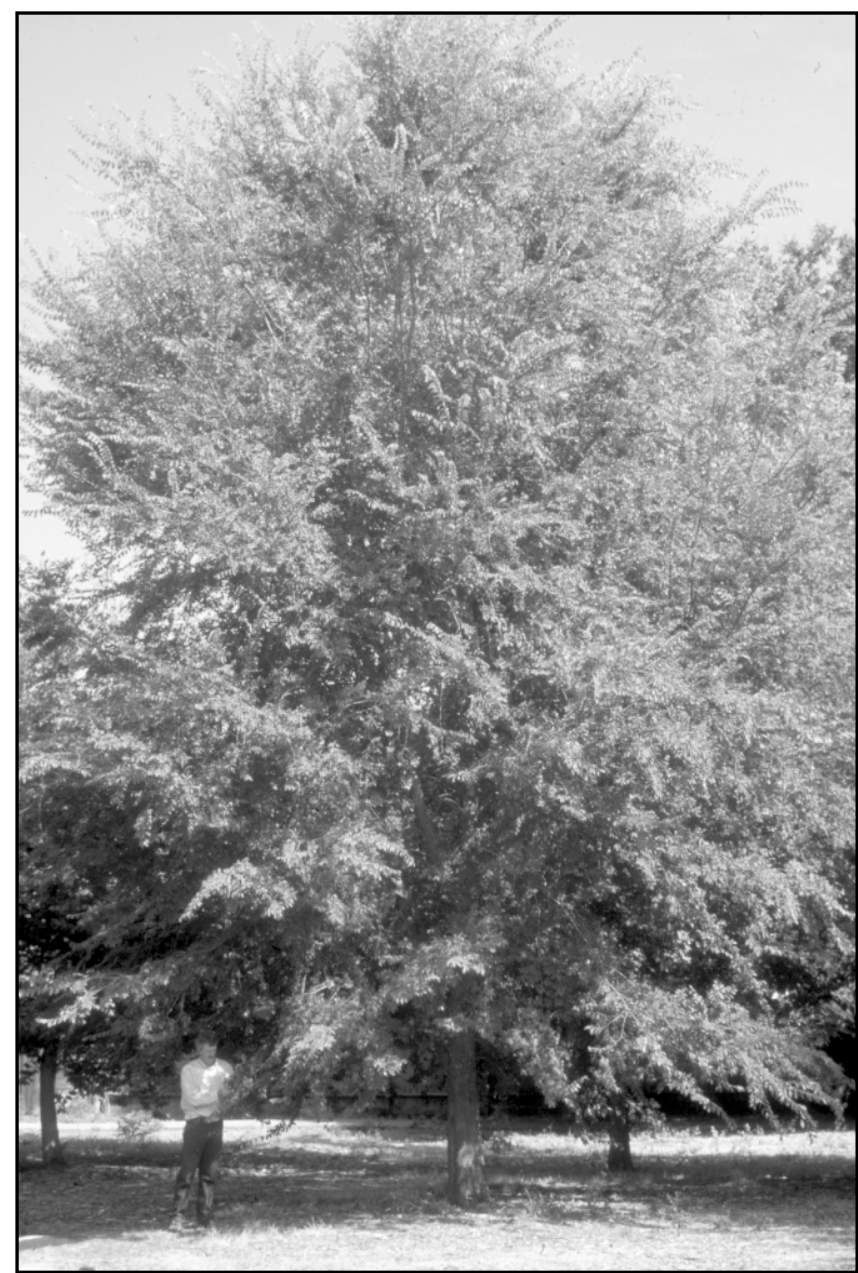

Figure 7. 'Frontier' developed a dominant central leader, strong branch attachments, and good branch-totrunk size relationships. Ten years after planting, this tree is approximately $11 \mathrm{~m}(33 \mathrm{ft}) \mathrm{tall}$.

\section{'American Liberty'}

When trained to remove codominant stems and weak branch attachments, 'American Liberty' developed strong structure and a form typical of American elm (Figure 8). It was found to have a relatively fast growth rate, and it exhibited good fall color (yellow). Susceptibility to ELB resulted in high levels of injury when ELB populations were high.

Given that 'American Liberty' is composed of six different "clones" (Smalley et al. 1993), it can be suggested that some variability in DED tolerance may be found among the clones. Regardless of this potential variability, however, evidence here indicates that at least one of these "clones" is susceptible to DED. In addition, a previous report found this cultivar to have low DED tolerance (Townsend and Douglass 2001), and two out of 16 'American Liberty' trees planted in 1998 in Piedmont, California, were found to have contracted DED (D. Frankel, pers. comm.). Collectively, this evidence indicates that 'American Liberty' is highly questionable as a replacement for DEDinfected elms in California. 


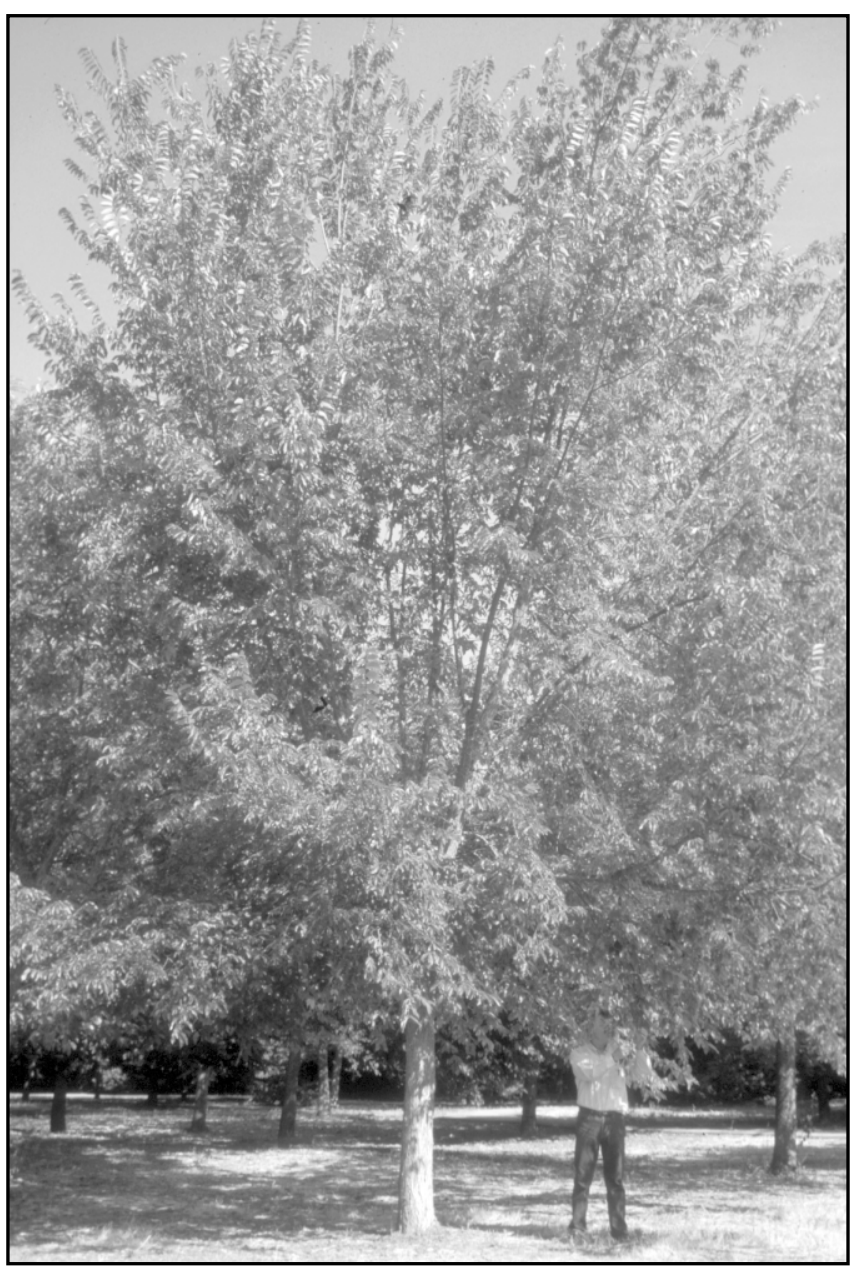

Figure 8. 'American Liberty' developed strong structure and a form typical of American elm. Initially, it needed formative pruning to remove codominant stems and weak branch attachments. Ten years after planting, this tree is approximately $9.5 \mathrm{~m}$ (31 ft) tall.

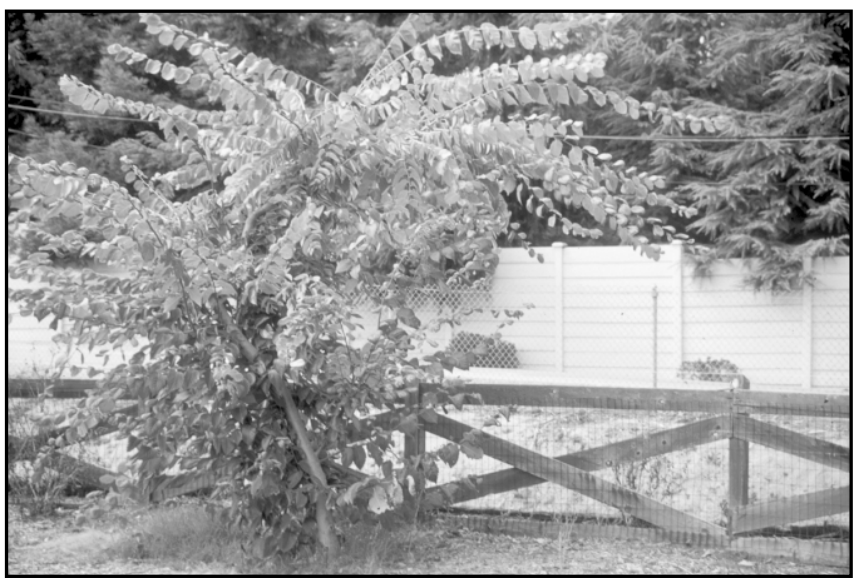

Figure 9. 'Valley Forge' exhibited a very fast growth rate and trees became "branch dominant." Attempts to develop a central leader were unsuccessful. Due to its poor structure, 'Valley Forge' was removed from the plot in 2002.

\section{'Valley Forge'}

Poor structural characteristics combined with a very rapid growth rate resulted in the removal of 'Valley Forge' from the test plot (Figure 9). Despite its reported high tolerance of DED (Townsend and Douglass 2001), 'Valley Forge' was deemed to be unsuitable because its maintenance requirement likely will be higher than that which most municipalities are willing to accept. The use of 'Valley Forge' may be limited to temperate climate zones where growth rate would not be expected to be as high.

Evaluations of pest tolerance and growth characteristics of 'Prospector', 'Frontier' and 'American Liberty' will continue over the next decade. When further results are found, an updated report will follow.

\section{LITERATURE CITED}

Becker, H. 1996. New American elms restore stately trees. USDA Agric. Res. 44(7):4-8.

California Department of Forestry and Fire Protection. 1990. Dutch Elm Disease Project: 1990 Annual Report. Forest Pest Management Program. California Dept. of Forestry and Fire Protection, Sacramento, CA.

Costello, L.R. 2002. Training young trees for structure and form. Tree Care Industry 13(7):48-54.

Costello, L.R., S.R. Scott, J.D. Peterson, and C.J. Adams. 1990. Trunk banding to control elm leaf beetle. J. Arboric. 16(9):225-230.

Costello, L.R., E.J. Perry, N.P. Matheny, J.M. Henry, and P.M. Geisel. 2003. Abiotic Disorders of Landscape Plants: A Diagnostic Guide. Publication \#3420. University of California Agriculture and Natural Resources, Oakland, CA. 242 pp.

Dreistadt, S.H., and D.L. Dahlsten. 1990. Relationships of temperature and elm leaf beetle (Coleoptera:

Chrysomelidae) development and damage in the field. J. Econ. Entomol. 83:837-841.

Dunn, C.P. (Ed). 2000. The Elms: Breeding, Conservation, and Disease Management. Kluwer Academic Publishers, Norwell, MA.

Frankel, D. 2003. Urban Forester, City of Piedmont, CA (personal communication).

Greenfield, J. 1996. Dutch elm disease: What are California communities doing? Calif. Trees 7(1):1-4.

Hall, R.W. 1986. Preference and suitability of elms for adult elm leaf beetle, Xanthogaleruca luteola (Coleoptera: Chrysomelidae). Environ. Entomol. 15:143-146.

Hall, R.W., and A.M. Townsend. 1987. Suitability of Ulmus wilsoniana, the 'Urban' elm, and their hybrids for the elm leaf beetle, Xanthogaleruca luteola (Muller) (Coleoptera: Chrysomelidae). Environ. Entomol. 16:1042-1044.

Hall, R.W., A.M. Townsend, and J.H. Barger. 1987. Suitability of thirteen different host species for elm leaf beetle, Xanthogaleruca luteola (Muller) (Coleoptera: Chrysomelidae). J. Environ. Hortic. 5:143-145. 
Kuser, J., and N. Polanin. 2001. Comparative test of six DEDtolerant elms: A preliminary report on nursery performance. J. Arboric. 27(5):281-282.

Luck, R.F, and G.T. Scriven. 1979. The elm leaf beetle, Pyrrhalta luteola, in southern California; Its host preference and host impact. Environ. Entomol. 8:307-313.

Markham, L., and A. Haley. 1990. 1990 Annual Lab Report of the Forest Pest Management Program. California Department of Forestry and Fire Protection, Sacramento, CA.

Smalley, E.B., P.R. Guries, and D.T. Lester. 1993. American Liberty elm and beyond: Going from the impossible to the difficult, pp 26-45. In Sticklen, M.B., and J.L. Sherald (Eds.). Dutch Elm Research: Cellular and Molecular Approaches. Springer-Verlag, New York, NY.

Tidwell, T.E. 1982. Isolation of Ceratocystis ulmi from deep annual rings of elms in California. Plant Dis. 66(11):1016-1018.

Townsend, A.M. 2000. USDA genetic research on elms, pp 271-278. In Dunn, C.P. (Ed.). The Elms: Breeding, Conservation, and Disease Management. Kluwer Academic Publishers, Norwell, MA.

Townsend, A.M. and L.W. Douglass. 2001. Variation among American elm clones in long-term dieback, growth, and survival following Ophiostoma inoculation. J. Environ. Hortic. 19(2):100-103.

Townsend, A.M., S.E. Bentz, and G.R. Johnson. 1995. Variation in response of selected American elm clones to Ophiostoma ulmi. J. Environ. Hortic. 13:126-128.

Townsend, A.M., L.R. Schreiber, W.O. Masters, and S.E. Bentz. 1991a. 'Frontier' elm. HortScience 26:80-81. . 1991b. 'Prospector' elm. HortScience 26:81-82.

Ware, G.H. 1992. Elm breeding and improvement at the Morton Arboretum. Morton Arboret. Q. 28:846-849.

Warren, K. 2000. The return of the elm, pp 341-348. In Dunn, C.P. (Ed.). The Elms: Breeding, Conservation, and Disease Management. Kluwer Academic Publishers, Norwell, MA.
Acknowledgments. The authors gratefully acknowledge and thank the many cooperators in this project: L. Schreiber, A. Townsend and W. Masters (U.S. National Arboretum); Y. Spalthoff (Elm Research Institute); R. Quadri and R. Langevin (City of Burlingame, California); G. Ginilo, G. Van Wassenhove, and the San Francisco Bay Area County Agricultural Commissioners; Zac Mousli and the University of Calfornia Bay Area Research and Extension Center staff; K. Jones (University of California Cooperative Extension); R. Hall and D. Carey (The Ohio State University); and C. Krass (California Department of Food and Agriculture) for their support and advice. We thank R. Moore, J. Mercer, M. Anderson, K. Anderson, and the Town of Atherton, California, for making this project possible and for their ongoing support; J. Butler, J. Rios, C. Martin, S. Steinhardt, and the California Department of Forestry and Fire Protection for their support and help in growing and planting the elms; and S. Fessenden for assistance in tree measurement. This project was funded in part by grants from the USDA Smith-Lever IPM Project and the University of California Division of Agriculture and Natural Resources.

\author{
${ }^{1 *}$ University of California \\ 146 Jordan Ave. \\ San Francisco, CA, 94118, U.S. \\ ${ }^{2}$ Urban Forester \\ City of Palo Alto \\ Palo Alto, CA, U.S. \\ ${ }^{3}$ Statistician \\ University of California, Davis \\ Davis, CA, U.S. \\ *Corresponding author.
}


Résumé. En 1992, trois cultivars d'ormes reportés comme ayant une tolérance à la maladie hollandaise de l'orme ont été plantés dans des unités en plein champs à Atherton en Californie. Les cultivars étaient 'Prospector', 'Frontier' et 'American Liberty'. Un quatrième cultivar, 'Valley Forge', a été ajouté dans ce champ en 1999. Des ormes d'Amérique produits à partir de semences ont aussi été plantés à titre de groupe-témoin. Durant la décennie 1992'02, la hauteur de l'arbre et le diamètre du tronc ont été mesurés annuellement, de même que des inspections ont été faites en regard des infections par la maladie hollandaise de l'orme, de l'activité des scolytes de l'orme et d'autres parasites. En août 2003, un orme 'American Liberty' s'est retrouvé infecté par la maladie hollandaise de l'orme. Ce fut le seul arbre qui a montré des symptômes d'infection depuis le début de l'étude. Lactivité des scolytes de l'orme a été la plus forte en 1993 et 1994, causant des dommages substantiels aux cultivars 'American Liberty' et 'Frontier' ainsi que dans le groupe-témoin. Le cultivar 'Prospector' a subi de faibles dommages. Lactivité par d'autres parasites s'est avérée faible la plupart des années. En 2002, les cultivars 'Frontier', 'American Liberty' ainsi que le groupetémoin avaient un accroissement en diamètre équivalent, et tous étaient significativement plus larges que ceux du cultivar 'Prospector'. Après 10 ans, 'Frontier' était le plus grand (11,3 m) et 'Prospector' le plus petit (6,9 m); 'American Liberty' ainsi que le groupe-témoin se situaient entre les deux (9,6 à 10,3 m respectivement). Les sujets appartenant au cultivar 'Valley Forge' ont été suivis pendant trois ans puis retirés de l'étude en raison de leur faible structure.

Zusammenfassung. 1992 wurden 3 Ulmenkultivare, die, wie berichtet, tolerant gegenüber DED sind, in einem Feldversuch in Atherton, California, gepflanzt. Die Kultivare waren: ,Prospector,' ,Frontier' und ,American Liberty'. 1999 wurde ein vierter Kultivar: Valley Forge hinzugefügt. Als Kontrolle wurden aus Samen gezogene amerikanische Ulmen dazugepflanzt. In der 10järigen Periode von 19922002 wurden Baumhöhe und Stammdurchmesser jährlich gemessen und Inspektionen auf DED-Infektionen, Ulmensplintkäferbefall und andere Krankheiten durchgeführt. Im August 2003 wurde eine mit DED infizierte ,American Liberty' gefunden. Dies ist der einzige Baum, der seit Studienbeginn Infektionssymptome gezeigt hat. Die Ulmenkäferaktivität war 1993 und 1994 am höchsten und verursachte an ,American Liberty,' ,Frontier' und den Kontrollpflanzen beträchtliche Schäden, während ,Prospector' nur geringe Schäden hatte. Andere Schädlingsaktivitäten sind in den meisten Jahren unbedeutend gewesen. 2002 wurden die Kultivare ,Frontier,' ,American Liberty' und Kontrollen mit gleichen Stammdurchmessern gefunden, die bedeutend größer als ,Prospector' waren. Nach 10 Jahren war ,Frontier' der größte (11,3 m), Prospector' am kürzesten (6,9 m) und ,American Liberty' und die Kontrollen lagen zwischen 9,6m und 10,3m. ,Valley Forge' wurde 3 Jahre überwacht und dann wegen schlechter Struktur aus der Studie entfernt.

Resumen. En 1992, tres cultivares de olmo reportados como tolerantes a la enfermedad holandesa del olmo (DED) fueron plantados en un parcela de campo en Atherton, California: Prospector', 'Frontier', y 'American Liberty'. Un cuarto cultivar, 'Valley Forge' fue añadido en 1999. Olmos americanos obtenidos de semillas fueron plantados como controles. En el período de 10 años, de 1992 a 2003, la altura del árbol y el diámetro del tronco fueron medidos anualmente y se hicieron inspecciones para infecciones de DED, actividad del escarabajo en la hoja y otras plagas. En agosto de 2003, un 'American Liberty' fue encontrado infectado con DED. Este es el único árbol que mostró síntomas de la infección desde el comienzo del estudio. La actividad del escarabajo fue mayor en 1993 y 1994, causando daño a 'American Liberty', 'Frontier' y los controles. 'Prospector' tuvo menos daño. El daño de otras plagas ha sido leve. En 2002, 'Frontier', 'American Liberty' y los controles presentaron un crecimiento del tronco equivalente y significativamente mayor que 'Prospector'. Después de 10 años, 'Frontier' fue el más alto (11.3 m), 'Prospector' fue el más pequeño $(6.9 \mathrm{~m})$ y 'American Liberty' y los controles estuvieron entre $9.6 \mathrm{~m}$ y $10.3 \mathrm{~m}$, respectivamente. 'Valley Forge' fue monitoreado por 3 años y luego removido del estudio debido a su pobre estructura. 